discipline and a means of protecting objects from unauthorized entry. As a scientific category, security equipment is a set of scientific statements and recommendations on the use of technical, software and hardware, software, substances, information systems, scientific and special methods of using them in the performance of tasks by subjects of security activity. The system and problems of security equipment are defined.

The security equipment system consists of elements, namely: general provisions, directions of application and functionality of security equipment. The legal basis for the use of security equipment and the organizational structures of its use for the protection of objects are highlighted. It is shown that the normative legal acts that constitute the legal basis for the protection of property and the use of technical means of protection belonging to various branches of law: constitutional, economic, civil, administrative, criminal. The categories "organization of technical protection of objects" and its classification are defined. The organization of technical protection of objects is a comprehensive system of certified detection, warning and other technical means designed to create the necessary level of object security and solve the tasks assigned to the security equipment during its operation by security subjects in accordance with regulatory documents.

Practice shows that the use of a specific system and types of technical means of protection is determined by the requirements of the subjects of protection, the number of protected and their distance from the point of centralized protection to which information is transmitted from technical means of protection. With the help of technical means of protection, you can organize three types of protection: autonomous, centralized; combined. A promising direction of development of security equipment are intelligent systems.

Key words: security equipment, security activity, category, classification, organization, perspective.

УДК 343.97

Христьян А. О.

судовий експерт сектору технічних досліджень документів та почерку відділу криміналістичних видів досліджень Запорізького Науково-дослідного експертнокриміналістичного изентру МВС України

(м. Запоріжжя, Україна)

\title{
ЗАСТОСУВАННЯ НОВІТНІХ ТЕХНОЛОГЙ ДЛЯ ПОПЕРЕДЖЕННЯ ТА ПРОФІЛАКТИКИ ЗЛОЧИНІВ
}

У статті з'ясовано значення технічних засобів для попередження, розкриття та профілактики злочинів. Наведено статистичні дані щодо аналізу стану злочинності в Україні за 2018 рік, а також подано технічні засоби профілактики злочинів. Зазначено про необхідність впровадження в Україні позитивного досвіду зарубіжних країн у застосуванні новітніх технологій.

Ключові слова: злочинність, злочин, профілактика, попередження, технічні засоби, криміналістична техніка, технології.

Постановка проблеми. Розмах і безкарність злочинності, застарілі технічні засоби попередження, розкриття та профілактики злочинів, не застосування новітніх технологій для попередження злочинів - ось що $є$ 
однією 3 найгостріших проблем суспільства багатьох країн світу. У Конституції України зазначено, що людина, іiі життя і здоров'я, честь і гідність, недоторканність і безпека визнаються в нашій країні найвищою соціальною цінністю, а утвердження й забезпечення прав і свобод людини є головним обов'язком держави [1]. Саме тому попередження злочинності має розглядатися як основний напрям політики держави у сфері боротьби зі злочинністю.

Аналіз останніх досліджень і публікацій. Проблему попередження та профілактики злочинів не оминуло увагою багато українських криміналістів, серед яких: О. М. Джужа, І. Г. Богатирьов, О. Ф. Гіда, В. П. Колмаков, Я. Ю. Кондратьєв, П. Д. Біленчук, В. В. Василевич та інших. Однак 3 огляду на те, що технічні засоби, які використовуються для попередження, розкриття та профілактики злочинів здебільшого $є$ застарілими й потребують оновлення, аспекти цієї проблеми вимагають дальшого дослідження.

Формування цілей. Метою статті є дослідження технічних засобів і новітніх технологій, що використовуються для попередження, розкриття та профілактики злочинів.

Виклад основного матеріалу. Визначити рівень правопорядку в суспільстві можна за допомогою показників статистики, яка дає вичерпну, науково-обгрунтовану інформацію про тенденції в розвитку злочинності, іiі рівень, динаміку, структуру, особу злочинця, причини та умови існування злочинності, а також про позитивні й негативні наслідки роботи правоохоронних органів з її попередження. Усе це дає змогу прогнозувати й розробляти науково-обгрунтовані заходи щодо попередження та профілактики окремих видів злочинів.

Згідно зі статистичними даними МВС упродовж дев'яти місяців 2018 року в Україні зменшилася кількість зареєстрованих злочинів порівняно 3 аналогічним періодом 2017 року - 3420 до 386 тисяч. До того ж кількість тяжких і особливо тяжких злочинів 3 цього числа зменшилася на 11 відсотків - зі 155 до 138 тисяч. Найбільший масив становлять крадіжки (191 тисяча) та шахрайства (27 тисяч). Також упродовж 2018 року прослідковується підвищення рівня розкриття тяжких і особливо тяжких злочинів. Зокрема, за три квартали 2018 року підрозділи поліції розкрили понад 148 тисяч кримінальних правопорушень [2].

Найнижчий рівень злочинності зафіксований у Донецькій і Луганській областях (на неокупованих територіях), а найбільша кількість правопорушень зареєстрована в Харкові, Одесі, Запоріжжі та Дніпрі.

Зауважимо, що в процесі історичного розвитку людство використовувало два основних способи протидії злочинності: покарання за вчинений злочин та профілактику злочинів.

Першим, хто висловив думку про те, що профілактика злочинності має мати пріоритет перед каральною політикою держави був Платон у IV cт. до н. е. Він вважав, що в суспільстві має діяти досконале законодавство, покликане відвертати людей від злочинів. Про те, що краще запобігти злочинній діяльності, ніж карати за ії вчинення, писали й італійський 
мислитель, засновник теорії кримінального права і теоретик кримінального права Ч. Беккаріа, а також великий французький мислитель XVIII ст. Ф. М. Вольтер. Цікавими також є роздуми Ч. Беккаріа про злочин i покарання. «Загалом вимагається - писав він, - щоб злочини не вчинялися i, особливо, щоб не вчинялися злочини, найбільш шкідливі для суспільства. Тому перепони, які стримують людей від учинення злочинів, мають бути тим міцнішими, чим важливішими є ті блага, на які посягають» [3].

В українській правничій літературі XVIII-XIX ст.ст. ідеї про переваги профілактики злочинів над покараннями за їх вчинення, про боротьбу зі злочинністю не покаранням, а їі запобіганням розвивали П. І. Пестель, Л. С. Белогриць-Котляревський, С. Ю. Десницький, О. Ф. Кістяківський, Л. Є. Владимиров та ін. [4, с. 6].

Значення профілактики злочинів як головного напряму протидії злочинності визначається трьома обставинами. По-перше, профілактика злочинів є найбільш гуманним засобом підтримки правопорядку та гарантією безпеки суспільства. Проведення такої діяльності забезпечує захист осіб, які мають схильність до вчинення злочинів, від морального падіння, не дає їм стати на шлях злочинності, позбавляючи тим самим кримінального покарання. По-друге, профілактика злочинів є найбільш ефективним засобом протидії злочинності, адже кримінальне покарання як регулятор людської поведінки має обмежені можливості. По-третє, профілактика злочинів є значною економією ресурсів суспільства, адже дешевше запобігти злочину, ніж витрачати кошти на його розкриття, розслідування, тримання під вартою осіб, які вчинили злочин, утримання такої кількості правоохоронних органів тощо [5].

Сутність профілактики злочинів полягає в усуненні або нейтралізації причин та умов, що призводять до правопорушення, а також у справлянні попереджувального впливу на нестійких членів суспільства, схильних до його вчинення. Певна роль у профілактичній діяльності належить усім наукам, зокрема й криміналістиці.

Скажімо, криміналістична техніка має велике значення в попередженні та профілактиці злочинів. Технічні засоби профілактики розробляють на підставі виявлення причин та умов, що сприяли вчиненню злочинів, вивченню та узагальненню слідчої, оперативно-розшукової та експертної практик. Важливим є також розроблення науково-технічних засобів протидії злочинності. Технічні засоби профілактики відрізняються від інших криміналістичних засобів тим, що їх застосовують до виникнення злочинного діяння. Вони перешкоджають вчиненню злочину або допомагають його виявленню.

До технічних засобів профілактики належать різні технології, пристрої, засоби й пристосування, що перешкоджають суспільно-небезпечним наслідкам у процесі соціальної діяльності людей, а також вчиненню злочинів та інших правопорушень (наприклад, технології, що унеможливлюють аварійність на дорогах, правила дорожнього руху, засоби охоронної та пожежної сигналізації, протиугонні та запираючі пристрої). 
П. Біленчук класифікує засоби криміналістичної профілактики за видами профілактичних завдань на п'ять груп:

1. Технічні засоби і методи, що використовують для виявлення фактів, які сприяли вчиненню або приховуванню злочинів.

До них він зараховує:

- техніку спеціаліста, помічника слідчого, а також технічні комплекти криміналістичної та оперативної техніки;

- засоби і методи експертного дослідження;

- прийоми і методи непроцесуального використання криміналістичної та оперативної техніки.

2. Технічні засоби і методи захисту різних об'єктів від злочинних посягань, наприклад, засоби охоронної сигналізації, засоби, які перешкоджають (заважають) вчиненню злочину.

3. Технічні засоби, що створюють умови виникнення на місці вчинення злочину додаткових слідів, наприклад, рук, звуку, запаху.

4. Технічні засоби і методи отримання інформації про злочини, що готуються. Це засоби спеціальної техніки, що застосовують органи дізнання під час оперативно-розшукової діяльності, скажімо, негласного документування злочинної діяльності фотозйомкою, відеозаписом, зняття інформації з лінії зв' язку тощо.

5. Технічні засоби і методи справляння активного психологічного впливу на осіб, схильних до вчинення правопорушень. До прикладу, використання телевізійних систем слідкування, установлених у місцях скупчення людей (аеропортах, вокзалах, банківських установах, магазинах тощо).

Скажімо, установлення телевізійних камер на ділянках доріг 3 інтенсивним рухом або з'явлення патрульного гелікоптера над автодорогами справляють серйозний вплив на водія, який порушує правила дорожнього руху [ 6, с. 72 - 73].

Зауважимо, що з 08 жовтня 2018 року в Україні на аварійно-небезпечних ділянках доріг міжнародного значення та в місцях концентрації ДТП патрульні поліцейські почали використовувати засіб для контролю за дотриманням водіями встановлених швидкісних режимів - пристрої вимірювання швидкості TruCam. Максимальна робоча дистанція для приладу TruCam - 1200 метрів. Порушення швидкісного режиму все одно буде зафіксовано, навіть якщо водій вирішить пригальмувати перед автомобілем патрульної поліції [7].

Оскільки розвиток новітніх технологій не стоїть на місці, то для попередження злочинів, учинених на транспортних засобах у стані алкогольного сп'яніння, винайдений алкозамок. Такий винахід для водія, який намагається завести двигун автомобіля, є непереборною перешкодою. При повороті ключа запалення алкозамок автоматично активується, пропонуючи водієві пройти миттєвий тест на вміст спиртової пари в організмі. Процедура здійснюється в спосіб подиху через спеціальний мундштук. Результати аналізу відображаються на спеціальному електронному дисплеї. Зазначимо, що подібні прилади застосовуються навіть для велосипедів, наприклад, замок Alcoho-Lock, винайдений 
японським веломагазином Koowho, 3 метою запобігання катання в нетверезому стані.

3 огляду на те, що протидії злочинності у розвинутих країнах світу надається важливе значення, виникає необхідність впровадження їх позитивного досвіду і в Україні.

Скажімо, у багатьох країнах світу для профілактики та запобігання злочинів популярними є технології розумного (інтелектуального) будинку Smart House, однією із невід'ємних складових якої є система захисту від несанкціонованого проникнення. До системи вміщено відеокамери, фотоелементи, що реагують на рух, детектори об'єму, контактні сенсори тощо, за допомогою яких здійснюється автоматична ідентифікація особи через аналізатори голосу, відбитки пальців рук чи райдужної оболонки ока [8, с. 916]. В Україні також можна скористатися відповідною технологією. Зокрема, винахідники 3 м. Дніпро розробили розумну систему безпеки «Branto». Цей гаджет має форму кулі та являє собою пристрій дистанційного управління «розумним будинком». Він оснащений модулями Wi-Fi, Bluetooth та інфрачервоним портом, що дає змогу під'єднати його до кондиціонера, розеток, освітлення, аудіосистеми й телевізора. Він має вбудовані динаміки та HD-камеру з кутом огляду $360^{\circ}$. Завдяки цьому господар може стежити за своїм будинком зі смартфона. У цій технології передбачено функцію «домашнього сторожа» - система нічного бачення й вбудовані сенсори миттєво попередять власника про підозрілу активність у приміщенні. Керувати системою можна за допомогою Google Glass.

Неможливо оминути й досягнення у сфері розробки й використання біометричних систем. До слова, це один з перспективних напрямів наукового дослідження, результати якого можуть ефективно використовуватися для запобігання вчиненню злочинів. До прикладу, дактилоскопічні біометричні системи (сканування відбитків пальців), біометричні системи розпізнавання обличчя (ідентифікація конкретного обличчя серед багатьох тисяч облич, зафіксованих у базі даних), біометричні системи розпізнавання особи за райдужною оболонкою ока (здатність приладів сканувати райдужну оболонку ока на відстані декількох десятків сантиметрів дає змогу використовувати їх у банкоматах. Ця технологія успішно застосовується останнім часом у державних установах США, а також на заводах з високим ступенем секретності) [9, с. 87-97].

Не так давно вчені Лестерського університету (Велика Британія) розробили пристрій, здатний розпізнавати людей і місцевість за запахом. Електронний ніс може визначити «власника» дихання або запаху тіла менше ніж за хвилину, аналізуючи летючі органічні сполуки та порівнюючи їх із наявними в базі даних. Тобто до набору біометричних даних про людину долучився ще один параметр - «відбиток запаху».

У містечку Альсгарде (Данія) системою охоронного телебачення DigiEуе було зареєстровано вбивство, скоєне в банку під час грабежу. Поліція не змогла відразу ідентифікувати грабіжників, які були в каптурах. Була використана нова технологія, яка об'єднує зображення, отримані за допомогою відеоохоронної системи та фотограмметричне програмне 
забезпечення PhotoModeler. Методика фотограмметричних вимірювань генерує точні 3D моделі й точні вимірювання пропорцій тіла за зображеннями охоронного телебачення. Анімація реберних моделей людей дала можливість з'ясувати, чи $є$ пропорції тіла й руху підозрюваних ідентичними пропорціям тіла й рухам зловмисників. Злочин було розкрито [10].

Шведська компанія з біотехнології розробила електронний мікрочіп RFID (radio-frequency identification) та запропонувала декільком сотням співробітників високотехнологічного офісу Epicenter в Швеції вживити його собі під шкіру. Мікрочіп вводять під шкіру за допомогою спеціального шприца та використовують для посвідчення особи та гарантування безпеки (наприклад, несанкціонованого доступу працівників до інших приміщень центру тощо) [11].

До речі, першим патент на чіпи для людей отримав доктор Даніель Мен iз США. Він хотів запровадити їх для пошуку безвісти зниклих або викрадених дітей. Джек Данлеп, підприємець з Арізони, запропонував систему «KIDSCAN». Його пристрій мав служити для пошуку дітей, яким був імплантований мікрочіп, що посилає сигнали супутникам. Ця система не була реалізована, але схожі системи існують. Скажімо, у Франції було запропоновано поміщати мікросхеми в одяг літніх людей 3 ментальними відхиленнями, щоб спостерігати за їх місцезнаходженням [12].

Японська компанія NEC, один з найбільших виробників електронної, комп'ютерної техніки та телекомунікаційного устаткування у світі, оголосила про те, що її розроблена система лицьового розпізнавання буде масово використовуватися під час літніх Олімпійських ігор 2020 року, а також Параолімпійських ігор у Токіо. Систему мають намір застосувати для ідентифікації осіб. Це стане першим випадком використання подібної технології для забезпечення безпеки на Олімпійських іграх. Система перевірятиме акредитованих людей за допомогою лицьового розпізнавання, а також спеціальної карти-перепустки зі вбудованим мікрочіпом, яку треба буде показати в камеру спеціального апарату [13].

Висновки. В Україні використовують значну кількість технічних засобів для попередження, розкриття та профілактики злочинів, але, на превеликий жаль, вони часто є застарілими та потребують оновлення. Це допоможе не тільки розкрити більше злочинів, а й надасть змогу попередити вчинення правопорушень. Для цього Україні треба брати приклад 3 іноземних країн, упроваджуючи так звану «розумну техніку» та нові технології заради подолання злочинності й забезпечення безпеки ії громадян. А особливо, якщо наша держава прагне стати повноправним членом Європейського Союзу.

\section{Використані джерела:}

1. Конституція України. Закон України від 28.06.1996 № 30. Відомості Верховної Ради України. URL : http://zakon.rada.gov.ua/laws/show/254к/96-вр. (дата звернення: 10.01.2019).

2. Нарада з підбиття підсумків роботи блоку кримінальної поліції від 20.10.2018. Офіційний веб-сайт Міністерства внутрімніх справ України. URL: 
http://mvs.gov.ua/ua/news/16243_U_2018_roci_zagalniy_riven_zlochinnosti_v_Uk raini_znizivsya_na_visim_vidsotkiv_FOTO.htm. (дата звернення: 21.12.2018).

3. Бандура О.О. Філософія права: навч. посіб. / за ред. М. В. Костицького, Б Ф. Чміля; Нац. академія внутрішніх справ України. Київ: Юрінком Інтер, 2000. 336 с.

4. Медицький І. Б. Запобігання злочинності: навч. посіб. Івано-Франківськ, 2008. $231 \mathrm{c}$.

5. Профілактика злочинів: підручник / О. М. Джужа, В. В. Василевич, О. Ф. Гіда та ін.; за заг. ред. д-ра юрид. наук, проф. О. М. Джужі. Київ : Атіка, 2011. 720 c.

6. Біленчук П. Д., Лисиченко В. К., Клименко Н. І. та ін. Криміналістика: підручник / за ред. П. Д. Біленчука, 2-ге вид., випр. і доп. Київ : Атіка, 2001. 544 с.

7. Офіційний веб-сайт Міністерства внутрішніх справ України. URL: http://mvs.gov.ua/ua/news/15898_Patrulna_policiya_miscyah_koncentracii_DTP_z _8_zhovtnya (дата звернення: 20.12.2018).

8. Маланчук П .М., Мантула А. П. «Young Scientist» 11 (51) November, 2017. «Перспективи розвитку криміналістичної техніки в розслідуванні, розкритті і попередженні злочинів». URL: http://molodyvcheny.in.ua (дата звернення: 19.11.2018).

9. Лисенко А. М., Мельник О. С. Застосування біометричних систем для ідентифікації особи. Вісник Київського національного університету імені Тараса Шевченка. 2004. С. 87-91.

10. Державна пенітенціарна служба України. Інститут кримінальновиконавчої служби. План-конспект проведення лекцій. Біометричні системи розпізнання людини. Укладач В. І. Пазиніч, 2016.

11. Факты/Lifestyle/Техника/ «В Швеции имплантируют чипы офисным работникам». URL: https:/ / fakty.com.ua (дата звернення: 10.11.2018).

12. Мікрочіпові імплантати - надзвичайна небезпека. 2013. URL: https:/ /gloria.tv/article/JyPkcsro (дата звернення: 10.11.2018).

13. «Систему распознавания лиц впервые задействуют в Олимпийских играх-2020». 2018. URL: http:/ /www.noc.by/news (дата звернення: 14.11.2018).

Стаття надіӥшла до редколегї 30.01.2019

Христьян А. А., судебный эксперт сектора технических исследований документов и почерка отдела криминалистических видов исследований Запорожского Научно-исследовательского центра МВД Украины (г. Запорожье, Украина)

\section{Применение новейших технологий для предупреждения и профилактики преступлений}

В статье выяснено значение технических средств для предупреждения, раскрытия и профилактики преступлений. Приведены статистические данные по анализу состояния преступности в Украине за 2018 год. Указаны технические средства профилактики преступлений. Сделан вывод о необходимости внедрения в Украине положительного опыта зарубежных стран в применении новейших технологий.

Ключевые слова: преступность, преступление, профилактика, предупреждение, технические средства, криминалистическая техника, технологии. 


\section{Khristian A. Using of Innovational Technologies for Crimes Precaution and Prevention}

Excessive and impunity of crime, obsolete technical means for the warning, detection and prevention of crime, the failure to use the latest technologies to prevent crime - this is one of the most acute problems of the society of many countries. Due to the fact that the given problem is paid much more attention in the developed countries of the world, it is necessary to introduce their positive experience and in our country.

In the modern world, prevention of crimes is important, which is to eliminate or neutralize the causes and conditions that lead to offenses, as well as to cope with the preventive influence on unstable members of society who are inclined to commit it. It prevents the commission of crimes or helps to detect them. Warning and prevention of crime is of immense importance, since it applies to the occurrence of a criminal act and harm to a person.

Some important role in preventive activities belongs to all sciences, not excluding criminalistics. The purpose of this article is to study the technical means and the latest technologies used to warning, detect and prevent crimes, and could significantly facilitate the work of not only law enforcement agencies but also allow the population to protect themselves from criminal activities on their own. The article clarifies the importance of technical means for the prevention, detection and warning of crimes. The statistics on the state of crime analysis in Ukraine for 2018 are presented. The following are technical means of crime prevention. As the development of the latest technologies does not stand in place, modern technologies and developments of foreign countries actively used by their society have been analyzed. The modern achievements of Ukrainian scientists and the latest Ukrainian developments that can be used to prevent crime in our country are not neglected either. Also, in this paper, it was noted about the achievements in the field of development and use of biometric systems, which is one of the promising areas of scientific research, the results of which can be effectively used to prevent the commission of crimes. The necessity of introducing positive experience of foreign countries in Ukraine in application of the latest technologies is mentioned, which will help not only to reveal more crimes, but also to prevent the commission of offenses.

Key words: crime, offense, prevention, warning, technical means, forensic technology, technology.

УДК 343.985.(477)

Щербинсъкий К. С.

здобувач Харківського державного університету внутрішніх справ (м. Харків, Україна)

\section{ОПЕРАТИВНА ПРОФІЛАКТИКА РОЗБОЇВ, ЯКІ ВЧИНЯЮТЬСЯ НЕПОВНОЛІТНІМИ}

У результаті аналізу теорії й практики оперативно-розшукової діяльності, узагальнення наукових ідей i підходів до вдосконалення оперативної профілактики злочинів та на підставі історичного розвитку основних способів протидії злочинності, у статті висвітлюються теоретичні погляди щодо визначення особливостей профілактики розбоїв, які вчиняються неповнолітніми, 